\title{
IMPROVEMENT OF THE MODEL OF TRANSFORMATION OF NITROGEN-CONTAINING SUBSTANCES IN A WATER BODY FOR THE SOLUTION OF NATURE MANAGEMENT PROBLEM
}

\author{
Oleg Proskurnin \\ Laboratory of formation problems, water quality control and \\ information systems of environmental management \\ Research Institution "Ukrainian Scientific Research Institute of Ecological Problems" \\ 6 Bakulina str., Kharkiv, Ukraine, 61166 \\ Kateryna Berezenko \\ Department of Ecology and Life Safety \\ Lugansk National Agrarian University \\ 44 Alchevskih str., Kharkiov, Ukraine, 61002 \\ Iryna Kyrpychova \\ Department of Ecology and Life Safety \\ Lugansk National Agrarian University \\ 44 Alchevskih str., Kharkiov, Ukraine, 61002 \\ Yana Honcharenko \\ Department of Ecology and Life Safety \\ Lugansk National Agrarian University \\ 44 Alchevskih str., Kharkiov, Ukraine, 61002 \\ Anatoly Jurchenko \\ Laboratory of environmental measures in agriculture and energy complexes \\ Research Institution "Ukrainian Scientific Research Institute of Ecological Problems" \\ 6 Bakulina str., Kharkiv, Ukraine, 61166
}

\begin{abstract}
In the article is considered the one of aspects of nature management regulation - an account of successive transformation of pollutants in a water body, that come with waste waters of industrial, municipal and agricultural enterprises. It is necessary at the determination of permissible pollutants emission with waste waters that doesn't allow the excess of the permissible level of substances content in the control point of a water body. This problem is considered on the example of successive transformation of nitrogen-containing substances in the following transformation order: organic nitrogen - ammonium nitrogen - nitrite nitrogen - nitrate nitrogen. The topicality of the modeling of nitrogen-containing substances is conditioned by their role in water ecosystems functioning. At that existent mathematical models of natural water quality formation that take into account substances transformation contain the large number of unknown parameters. So, the use of such models in problems of nature management regulation is problematic, because identification of model parameters is a separate very complicated scientific problem. And existent models with relatively small number of parameters don't take into account the natural pollution of water bodies, caused by the life activity of organisms; substance losses in the transformational chain are also possible. The improved matrix mathematical model of nitrogen-containing substances transformation without the indicated shortcomings is offered.
\end{abstract}

Keywords: wastewater, water body, pollutant, nitrogen-containing substances, nature management regulation, model of pollutants transformation.

(C) Oleg Proskurnin, Kateryna Berezenko, Iryna Kyrpychova, Yana Honcharenko, Anatoly Jurchenko

\section{Introduction}

Water resources are the base of existence of humans, animal and vegetable world. Water resources reserve also influences an economic development of a country and a level of social prosperity of its dwellers. 
At the same time these resources are rather limited and slowly reproduced. That is why in existent circumstances - the growth of anthropogenic load on all components of natural environment - there is a necessity in a complication of rules of water resources management in the aspect of their more rational use and protection $[1,2]$.

The one of most essential sources of water bodies (WB) pollution is wastewater (WW) emission of industrial, municipal and agricultural enterprises [3]. That is why the one of most urgent environmental problem is nature management regulation [4]. Within this problem drainage standards are elaborated for enterprises - water-users - limit masses of substances, which emission doesn't result in a breaking of the needed water quality of WB. (In EU countries it is ELV - emission limit value, in post-soviet ones LPE - limit permissible emissions). The subtask of the determination of permissible concentrations of substances in WW is a prognostication of WB water quality in WW emission zone.

At that pollutants in water environment may undergo transformations as a result of chemical and biological process. Existent mathematical models of natural water quality formation that take into account substances transformation contain the large number of unknown parameters [5]. It makes their use in problems of nature management regulation problematic, because identification of model parameters is a separate very complicated scientific problem. And the existent model with relatively small number of parameters doesn't take into account the natural pollution of water bodies, caused by the life activity of organisms and possible substance losses in the transformational chain [6]. So, the improvement of this mathematical model in the aspect of indicated shortcomings elimination is urgent.

\section{Aim of research}

The aim of research is the improvement of the mathematical model of nitrogen-containing substances transformation process, described in the work [6]. The improved model must be suitable for the use in nature management regulation problems.

\section{Review of literary resources}

The European approach to drainage regulation is based on the requirement of non-excess of pollutants content within WW emission zone influence. In particular, art. 13 of the EU Water Framework Directive 2000/60/EC requires water protective decisions making "as closer as possible to the locations where water is affected or used" [4]. The analogous approach is accepted in the USA and in the post-soviet space [7]. In particular, art. 44 of the Water code of Ukraine puts on water users the responsibility for providing the required amount of natural water in control ranges of WB [8]. Their location is regulated by national legislations. In separate cases its remoteness from WW emission depends on watercourse parameters [9-11]. In other ones (for example, in Ukraine and in Russian Federation) it is the distinctly determined distance $-500 \mathrm{~m}$ downstream from the emission [12].

The important moment in the European approach is the dependence of WW emission standards on existent water purification technologies. At that emission standards are set in two stages. At the first stage the permissible WW content is set based on possibilities of available purification technologies. If rated pollutants concentrations in the control range exceed the set standard of the river water quality, at the second stage the requirements to WW content up to the safe level are toughened [13-15].

The Ukrainian methodological base of calculations is the "Instruction on LPE development and acceptance..." [12]. It orders to make a calculation of allowable substances concentrations in WW based on hydrological and hydrochemical WB parameters, WW volumes and also water consumption category (fishing, cultural-household and housing-drinking).

The "Instruction..." is based on the optimization approach to LPE calculation that takes into account substances transformation and is, in fact, reduced to the optimal drainage management [16]. The criterion of optimality - minimum summary costs for achieving LPE:

$$
Z=\sum_{i=1}^{m} f\left(x^{i}\right) \rightarrow \min
$$


where $\mathrm{f}$ - given costs of $\mathrm{i}$-th water user for achieving LPE; $\mathrm{x}^{\mathrm{i}}=\left(\mathrm{x}_{1}^{\mathrm{i}}, \ldots, \mathrm{x}_{\mathrm{r}}^{\mathrm{i}}\right)$ - vector of optimized variables, determining shares of discharge of waste waters that pass by different technological routes of their purification at i-th enterprise; $m$ - number of water users.

The composition of waste water at the outlet of treatment plants is determined by the formula

$$
C^{i}=\sum_{r=1}^{R_{i}} C_{r}^{i} \cdot x_{r}^{i},
$$

where $C_{r}^{i}$ - composition of WW of $i$-th emission, purified by the route $r, m g / \mathrm{dm}^{3} ; R_{i}-$ number of technological routes of purification of $\mathrm{WW}$ of $\mathrm{i}$-th emission.

Imitations of optimization problem are following:

$$
\left\{\begin{array}{l}
C_{j}^{C C} \leq C_{j}^{L P C}, j=1 \div n \\
x_{j}^{i} \leq C_{j}^{i}, j=1 \div n, i=1 \div m \\
x_{j}^{i} \geq C_{j}^{L P C}, j=1 \div n, i=1 \div m,
\end{array}\right.
$$

where $n$ - number of pollutants; $C_{j}^{i}, C_{j}^{K C}$ - actual concentrations of $j$ substance in $i$-th emission of $\mathrm{WW}$ and in the control range respectively; $\mathrm{C}_{\mathrm{j}}^{\mathrm{LPC}}-$ limit permissible concentration (LPC) of $\mathrm{j}$-th substance.

At the calculation of pollutants concentrations in the control range $\mathrm{C}_{\mathrm{j}}^{\mathrm{KC}}$ chemical and biochemical transformations of substances in WB, and for suspended matters - mechanical sedimentation, are taken into account. Four possible situations may be separated:

1) absence of any processes that influence the amount of substance in water (in such a case it is used to say that a pollutant is "conservative");

2) self-purification of WB by separate parameters - transformation of pollutant substance in forms, not considered as pollutants;

3) successive transformation - unidirectional transformation of substances into other ones, also considered as pollutants (most typical example - successive transformations of organic nitrogen into ammonium, nitrite and nitrate) [17, 18];

4) mutual transformation.

In the first case WB water composition changes only under the influence of conservative substances supply from different sources. The calculation of a concentration is realized based on the simple mass balance.

The fourth case may take place at absorption of nitrogen mineral compounds (nitrates, nitrites, ammonium) by plants. They are assimilated by plants at photosynthesis and comes into the composition of tissues of their organisms, and if animals eat these plants, in their organisms also. The reverse transformation of nitrogen from complicated organic compounds may take place at biochemical decay of nitrogen-containing organic compounds [19]. But it is rather specific situation that is not considered in this article.

If water self-purification takes place, its intensity, expressed by non-conservativeness coefficient, and natural background concentration of the considered substance, are taken into account. The mathematical model of self-purification is following:

$$
\mathrm{C}(\mathrm{t})=\left(\mathrm{C}_{0}-\mathrm{C}_{\mathrm{nat}}\right) \cdot \exp (-\mathrm{kt})+\mathrm{C}_{\text {nat }} \text {, }
$$

where $\mathrm{t}$ - time, $\mathrm{C}_{0}, \mathrm{C}(\mathrm{t})$ - substance concentration in the initial moment and in $\mathrm{t}$ moment respectively; $\mathrm{C}_{\text {nat }}$ - natural substance concentration; $\mathrm{k}$ - substance non-conservativeness coefficient.

Numerical values of $\mathrm{k}$ coefficient may be approximately accepted by reference data [6]. But self-purification intensity depends on water vegetation type and WB hydrological characteristics, so the determination of more precise values of $\mathrm{k}$ coefficients needs a separate study of WB properties. 
Substances transformation is a very complicated biochemical process. In 1980-ies RSIWP specialists elaborated mathematical models of surface water quality formation, presented as a system of differential equations [5]. But the indicated models include tens of examples, which identification in general case needs an independent research work on the study of concrete WB. So, the use of such models is unacceptable for finding the permissible WW composition.

Thus, the choice of an adequate transformational model to find the permissible WW composition is an urgent ecological problem.

\section{Materials and methods}

\section{1. Statement of the problem of drainage regulation for nitrogen-containing substances} transformation

In problems of drainage regulation for nitrogen-containing substances transformation (in the succession organic nitrogen - ammonium nitrogen - nitrite nitrogen - nitrate nitrogen) the following matrix model is used [6]:

$$
\mathrm{C}(\mathrm{t})=\mathrm{A}(\mathrm{t}) \cdot \mathrm{C}_{0}
$$

where $\mathrm{C}_{0}, \mathrm{C}(\mathrm{t})$ - vectors of substances concentrations at the initial moment and in $\mathrm{t}$ moment respectively; A ( $\mathrm{t})$ - transformation matrix.

As far as the reaction flows in one direction, for mathematic notational convenience it is expedient to index substances in the succession, correspondent to their chemical transformation. In this case the transformation matrix A $(t)$ is triangular and its nonzero elements are determined by the formulas, presented in the work [6].

The model (5) provides, at first, the linear dependence of the speed of concentration decrease on the current concentration. At second, this model provides the transformation of one substance into another without losses that is with observance of the full balance of nitrogen mass. For example, according to the model, the full transformation of organic nitrogen into ammonium one takes place. But in general case other decay products, not considered in the transformational chain, are possible. At second, a share of a substance may be absorbed by the water biota, at third, a share of a substance may transform in gas form and evaporate. At the same time the model (5) ignores the natural component of substances content in WB [20-22].

So, the model of nitrogen-containing substances transformation may be written in the following way:

$$
\mathrm{C}(\mathrm{t})=\mathrm{A}(\mathrm{t}) \cdot \mathrm{C}_{0}+\mathrm{B}(\mathrm{t})
$$

where B - vector, characterizing the natural component of substances content in WB.

Thus, the problem is reduced to finding transformation matrix $\mathrm{A}(\mathrm{t})$ elements and vector $\mathrm{B}(\mathrm{t})$.

\section{2. The solution of the problem of drainage regulation for nitrogen-containing substances transformation}

The finding of transformation matrix $\mathrm{A}(\mathrm{t})$ elements is realized based on the following conditions:

- concentration decreases to the level of the natural background (like at self-purification);

- only the linear component of the dependence of the concentration change intensity on the current concentration is considered.

The base for accepting these conditions may be the research results, presented in the works [5].

The dynamics of 1-st substance concentration (in this case, organic nitrogen) is described by the formula (1), so we have:

$$
\begin{gathered}
\mathrm{a}_{11}=\exp \left(-\mathrm{k}_{1} \cdot \mathrm{t}\right), \\
\mathrm{b}_{1}=\mathrm{C}_{\text {nat } 1}-\mathrm{C}_{\text {nat } 1} \exp \left(-\mathrm{k}_{1} \cdot \mathrm{t}\right) .
\end{gathered}
$$


The finding of elements $a_{21}, a_{22}$ and $b_{2}$ is realized in the following way. According to accepted assumptions, it may be written:

$$
\mathrm{dy}_{2}=-\mathrm{k}_{2} \cdot \mathrm{y}_{2} \cdot \mathrm{dt}+\mathrm{p}_{1} \cdot \mathrm{y}_{1} \cdot \mathrm{dt}
$$

where $\mathrm{y}_{1}, \mathrm{y}_{2}$ - concentration excess of 1 and 2 substances in the transformational chain over background concentrations; $p_{1}$ - transformation coefficient of 1 substance into 2 .

Taking into account the dependence (1):

$$
y_{i}(t)=\left(C_{0 i}-C_{n a t i}\right) \cdot \exp \left(-k_{i} \cdot t\right) .
$$

Thus, the differential equation for finding 2 substance concentration is following:

$$
\mathrm{y}_{2}^{\prime}+\mathrm{k}_{2} \mathrm{y}_{2}=\mathrm{p}_{1} \cdot \mathrm{y}_{01} \cdot \exp \left(-\mathrm{k}_{1} \cdot \mathrm{t}\right)
$$

where $\mathrm{y}_{01}$ - initial concentration excess of 1 substance over the natural background.

The solution of the equation (11) is following (solution mechanism is omitted):

$$
\mathrm{y}_{2}=\frac{\mathrm{y}_{01} \cdot \mathrm{p}_{1}}{\mathrm{k}_{2}-\mathrm{k}_{1}}\left(\exp \left(-\mathrm{k}_{1} \cdot \mathrm{t}\right)-\exp \left(-\mathrm{k}_{2} \cdot \mathrm{t}\right)\right)+\mathrm{y}_{02} \cdot \exp \left(-\mathrm{k}_{2} \cdot \mathrm{t}\right)
$$

Proceeding to concentrations, finally get:

$$
\mathrm{C}_{2}(\mathrm{t})=\mathrm{a}_{21} \cdot \mathrm{C}_{01}+\mathrm{a}_{22} \cdot \mathrm{C}_{02}-\mathrm{a}_{21} \cdot \mathrm{C}_{\text {nat } 1}+\mathrm{a}_{22} \cdot \mathrm{C}_{\text {nat } 2},
$$

where

$$
\mathrm{a}_{21}=\frac{\mathrm{p}_{1}}{\mathrm{k}_{2}-\mathrm{k}_{1}}\left(\exp \left(-\mathrm{k}_{1} \cdot \mathrm{t}\right)-\exp \left(-\mathrm{k}_{2} \cdot \mathrm{t}\right)\right) ; \quad \mathrm{a}_{22}=\exp \left(-\mathrm{k}_{2} \cdot \mathrm{t}\right)
$$

From the equation (12) also flows:

$$
\mathrm{b}_{2}=\mathrm{C}_{\text {nat } 2}-\mathrm{a}_{21} \cdot \mathrm{C}_{\text {nat } 1}-\mathrm{a}_{22} \cdot \mathrm{C}_{\text {nat } 2} \cdot
$$

The last elements of the matrix A and vector B are found in the analogous way:

$$
\left\{\begin{array}{l}
a_{j j}=\exp \left(k_{j} \cdot t\right), j=1 \div 4, a_{21}=f(1,2,1), a_{31}=g(1,1,2) \cdot f(3,1,3), a_{32}=f(2,2,3) ; \\
a_{41}=g(1,1,2) \cdot\{g(2,1,3) \cdot[f(3,1,3)-f(3,3,4)]-g(2,2,3) \cdot[f(3,2,4)-f(3,3,4)]\} ; \\
a_{42}=g(2,2,3) \cdot[f(3,2,4)-f(3,3,4)], a_{43}=f(3,3,4) ; \\
b_{j}=C_{\text {пр }}-\sum_{i=1}^{j} a_{i j} \cdot C_{\text {прi }}, j=1 \div 4 .
\end{array}\right.
$$

where $\mathrm{k}_{\mathrm{j}}, \mathrm{j}=1 \div 4,-$ transformation coefficients;

$$
\begin{gathered}
g(j, i, l)=p_{j} /\left(k_{i}-k_{1}\right) ; \\
f(j, i, l)=g(j, i, l) \cdot\left[\exp \left(k_{i} \cdot t\right)-\exp \left(k_{1} \cdot t\right)\right] .
\end{gathered}
$$

As it can be seen from (15), the offered model includes seven parameters that give a possibility to use it in practice in drainage regulation problems. In the case of full transformation of 
one substance into another and the natural background absence the equation (4) coincides with the correspondent one in [6] that indirectly testifies to the solution reliability.

The identification of matrix model parameters may be realized by the statistical processing of natural observations $[23,24]$. At absence of the representative sample of observations for the statistical analysis or absence of other information that allows to assess transformation model parameters, the calculation is realized simplistically: the full transformation of one substances to another ones is provided $\left(\mathrm{p}_{\mathrm{i}}=\mathrm{k}_{\mathrm{i}}\right)$, and reference values are chosen for transformation coefficients [20].

\section{Conclusions}

The matrix model of the transformation process of nitrogen-containing pollutants in natural water, as opposite to the existent model, presupposes possible substance losses in the transformational chain and also the natural pollution of water bodies. So, the offered model is more adequate to the considered biochemical process. It may be used in nature management regulation problems. Namely at limit permissible emissions of pollutants that come in a water body with WW.

The direction of further research in this field is the study of water bodies' properties and also the experimental verification of the offered model reliability.

\section{References}

[1] Momblanch, A., Paredes-Arquiola, J., Andreu, J. (2017). Improved modelling of the freshwater provisioning ecosystem service in water scarce river basins. Environmental Modelling \& Software, 94, 87-99. doi: 10.1016/j.envsoft.2017.03.033

[2] Momblanch, A., Paredes-Arquiola, J., Munné, A., Manzano, A., Arnau, J., Andreu, J. (2015). Managing water quality under drought conditions in the Llobregat River Basin. Science of The Total Environment, 503-504, 300-318. doi: 10.1016/j.scitotenv.2014.06.069

[3] Ayuso, R. A., Foley, N. K. (2016). Pb-Sr isotopic and geochemical constraints on sources and processes of lead contamination in well waters and soil from former fruit orchards, Pennsylvania, USA: A legacy of anthropogenic activities. Journal of Geochemical Exploration, 170, 125-147. doi: 10.1016/j.gexp10.2016.08.008

[4] EU Water Framework Directive 2000/60/EC of the European Parliament and of the Council of 23 October 2000 establishing a framework for Community action in the field of water policy (2000). Official Journal of the European Communities, 43 (22.12), 72.

[5] Plis, Yu. M. (1987). Otsenka kachestva troficheskih funktsiy pri modelirovanii biohimicheskoy transformatsii veschestv. Ohrana vod rechnyih basseynov, 16, 65-72.

[6] Hvat, V. A., Lvov, V. N., Ladyizhenskiy, V. N. (1989). Spravochnik po ohrane vodnyih resursov. Kyiv: Urozhay, 176.

[7] Morelissen, R., Kaaij, T.van der, Bleninger, T. (2011). Waste Water Discharge Modelling With Dynamically Coupled Near Field and Far Field Models. International Symposium on Outfall Systems.

[8] Vodnyiy kodeks Ukrainyi (v redaktsii 2016). Available at: http://zakon5.rada.gov.ua/laws/ show/213/95-\%D0\%B2\%D1\%80/page

[9] Morelissen, R., Vlijm, R., Hwang, I., Doneker, R. L., Ramachandran, A. S. (2015). Hydrodynamic modelling of large-scale cooling water outfalls with a dynamically coupled near-field-far-field modelling system. Journal of Applied Water Engineering and Research, 4 (2), 138-151. doi: 10.1080/23249676.2015.1099480

[10] Doneker, R. L. (2006). Systems Development for Environmental Impact Assessment of Concentrate Disposal- Development of Density Current Simulation Models, Rule Base, and Graphical User Interface. DWPR Report No. 132, US Bureau of Reclamation.

[11] Bleninger, T., Jirka, G. H. (2007). First Steps in Modeling and Design of Coastal Brine Discharges", International Desalination \& Water Reuse Quarterly. International Desalination Association, 17 (2), 48-55.

[12] Instruktsiya pro poryadok rozrobky ta zatverdzhennya hranychno-dopustymykh skydiv (HDS) rechovyn u vodni ob’yekty iz zvorotnymy vodamy (1994). Kharkiv: UkrNTsOV, 79.

[13] Jirka, G. H. (2008). Improved Discharge Configurations for Brine Effluents from Desalination Plants. Journal of Hydraulic Engineering, 134 (1), 116-120. doi: 10.1061/(asce)0733-9429(2008)134:1(116) 
[14] Jones, G. R., Nash, J. D., Doneker, R. L., Jirka, G. H. (2007). Surface Discharges into Water Bodies. I: Flow Classification and Prediction Methodology. Journal of Hydraulic Engineering.

[15] Hajigholizadeh, M., Melesse, A. M. (2017). Assortment and spatiotemporal analysis of surface water quality using cluster and discriminant analyses. CATENA, 151, 247-258. doi: 10.1016/j.catena.2016.12.018

[16] Proskurnin, O. A. (2014). Razbienie basseyna reki na lokalnyie uchastki s tselyu osuschestvleniya basseynovogo printsipa rascheta dopustimyih sbrosov stochnyih vod. Kommunalnoe hozyaystvo gorodov, $112,82-87$.

[17] Tinta, T., Kogovšek, T., Turk, V., Shiganova, T. A., Mikaelyan, A. S., Malej, A. (2016). Microbial transformation of jellyfish organic matter affects the nitrogen cycle in the marine water column $-\mathrm{A}$ Black Sea case study. Journal of Experimental Marine Biology and Ecology, 475, 19-30. doi: 10.1016/j.jembe.2015.10.018

[18] Ma, L., He, F., Huang, T., Zhou, Q., Zhang, Y., Wu, Z. (2016). Nitrogen and phosphorus transformations and balance in a pond-ditch circulation system for rural polluted water treatment. Ecological Engineering, 94, 117-126. doi: 10.1016/j.ecoleng.2016.05.051

[19] Boulard, T., Roy, J.-C., Pouillard, J.-B., Fatnassi, H., Grisey, A. (2017). Modelling of micrometeorology, canopy transpiration and photosynthesis in a closed greenhouse using computational fluid dynamics. Biosystems Engineering, 158, 110-133. doi: 10.1016/j.biosystemseng.2017.04.001

[20] Watanabe, A., Tamaki, N., Yokota, K., Matsuyama, M., Kokeguchi, S. (2016). Monitoring of bacterial contamination of dental unit water lines using adenosine triphosphate bioluminescence. Journal of Hospital Infection, 94 (4), 393-396. doi: 10.1016/j.jhin.2016.08.001

[21] Menon, S., Ganti, H., Niemeyer, K. E., Hagen, C. (2017). Effects of oil and water contamination on natural gas engine combustion processes. Journal of Natural Gas Science and Engineering, 41, 30-39. doi: 10.1016/j.jngse.2017.02.038

[22] Santos, R., Joyeux, A., Besnard, A., Blanchard, C., Halkett, C., Bony, S. et. al. (2017). An integrative approach to assess ecological risks of surface water contamination for fish populations. Environmental Pollution, 220, 588-596. doi: 10.1016/j.envpol.2016.10.007

[23] Ashraf, J., Uddin, S. (2016). New public management, cost savings and regressive effects: A case from a less developed country. Critical Perspectives on Accounting, 41, 18-33. doi: 10.1016/j.cpa.2015.07.002

[24] Nardi, D., Lampani, L., Pasquali, M., Gaudenzi, P. (2016). Detection of low-velocity impact-induced delaminations in composite laminates using Auto-Regressive models. Composite Structures, 151, 108-113. doi: 10.1016/j.compstruct.2016.02.005 